\title{
CORRIGENDUM
}

Genes \& Development 23: 2887-2899 (2009)

\section{Corrigendum: Quantitative proteomic analysis of purified yeast kinetochores identifies a PP1 regulatory subunit}

Bungo Akiyoshi, Christian R. Nelson, Jeffrey A. Ranish, and Sue Biggins

In the above-mentioned article, it has come to the authors' attention that the Supplemental Material incorrectly reports a mutation in the Fin $1^{\text {glc7- }}$ plasmid (pSB1237). It was originally reported that two mutations (L121 and F123) were made in the first of the five PP1-binding sites in the Fin1 protein. However, there is only a single mutation present (F123). This does not alter any of the properties of the mutant protein or any of the conclusions in this article. The authors apologize for this error.

doi: $10.1101 / \operatorname{gad} .291450 .116$ 


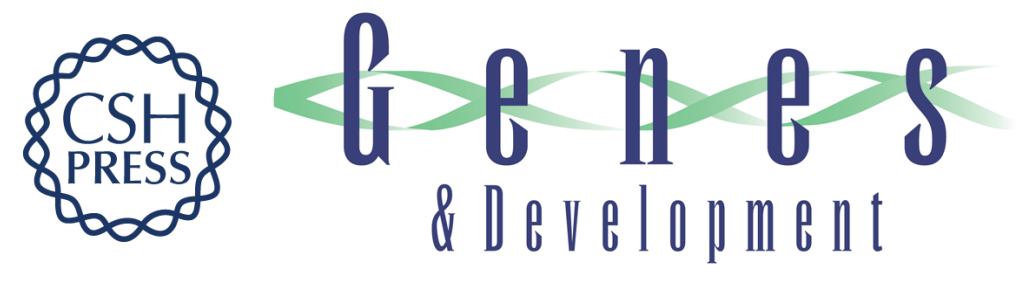

\section{Corrigendum: Quantitative proteomic analysis of purified yeast kinetochores identifies a PP1 regulatory subunit}

Bungo Akiyoshi, Christian R. Nelson, Jeffrey A. Ranish, et al.

Genes Dev. 2016, 30:

Access the most recent version at doi:10.1101/gad.291450.116

Related Content

Quantitative proteomic analysis of purified yeast kinetochores identifies a PP1 regulatory subunit

Bungo Akiyoshi, Christian R. Nelson, Jeffrey A. Ranish, et al.

Genes Dev. December , 2009 23: 2887-2899

\section{License}

Email Alerting

Service
Receive free email alerts when new articles cite this article - sign up in the box at the top right corner of the article or click here.

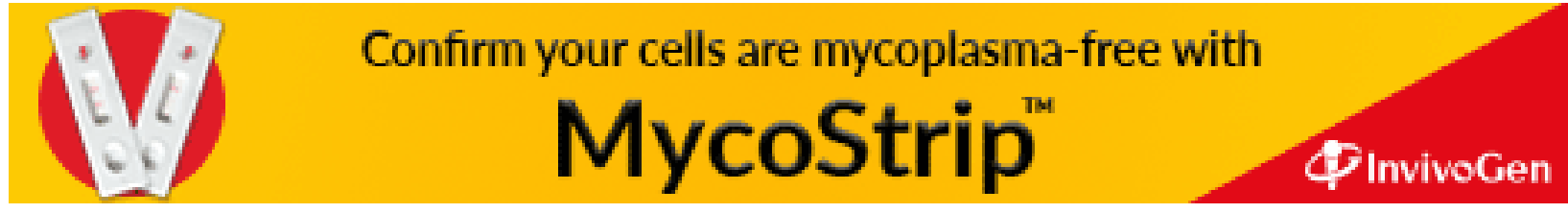

